\title{
Dynamics of vegetation structure and composition within early regeneration forest in the Danau Bangko Protected Area, Jambi, Indonesia
}

\author{
Asep Sadili ${ }^{1,2}$, Dolly Priatna ${ }^{1}$, and Sutanto $^{1}$
}

${ }^{1}$ Graduate School of Environmental Management, Pakuan University, Jl. Pakuan Kotak Pos 452, Bogor 16129, Indonesia ${ }^{2}$ Research Center for Biology (Botany Division), Indonesian Institute of Sciences, Jl. Raya Jakarta-Bogor Km 46, Cibinong, Bogor 16911, Indonesia

Corresponding author: Dolly Priatna,dollypriatna@unpak.ac.id

\begin{abstract}
An analysis of the growth dynamics of a 1-ha $(100 \mathrm{~m}$ x $100 \mathrm{~m})$ permanent plot was carried out in the Danau Bangko Protected Area (DBPA) in March 2020. DBPA is part of the industrial plantation forest concession of PT Rimba Hutani Mas (PT RHM) in Jambi Province. The study aims to determine the dynamics of vegetation structure and composition between 2018 and 2020 in early regeneration forest. All trees tagged in 2018 were remeasured in 2020. Trees that had not been tagged previously but were $\geq 10 \mathrm{~cm}$ in diameter at breast height $(\mathrm{DBH})$ were identified as a new recruit and tagged with a new number. Observations and data analysis were carried out on three stages of growth phases, namely in the tree phase $(\geq 10 \mathrm{~cm}$ $\mathrm{DBH})$, sapling phase $(<10 \mathrm{~cm} \mathrm{DBH})$, and seedling phase (height $<1.5 \mathrm{~m})$. The results showed that the number of species, genera, and families within the tree and sapling phases were high, but were low in the seedling phase. The dominant species in the tree phase in 2018, Alseodaphne bancana, had been replaced by Archidendron bubalinum in 2020, whereas the dominant species in the sapling phase (Rothmania sp.) and seedling phase (Aporusa microsphaera) remained the same from 2018 to 2020 . Mortality rates in all growth phases (tree, sapling and seedling) together is $4.67 \%$. Recruitment into the tree phase from 2018 to 2020 was $2.67 \%$, consisting of eight species, eight genera, and seven families. Within one hectare permanent plot, all members of each tree species were distributed randomly. The vertical structure of the forest area is dominated by stratum $\mathrm{C}$ (4-20 m height). The results of hypothesis testing for each phase (tree, sapling, seedling) were different, however overall the results showed that the plot structure and composition had changed.
\end{abstract}

\begin{abstract}
ABSTRAK
Studi dinamika hutan dilakukan di Kawasan Lindung Danau Bangko (KLDB) pada Maret 2020 dengan menggunakan pendekatan plot permanen seluas satu hektar (100 m x 100 m). KLDB merupakan bagian dari konsesi hutan tanaman industri PT Rimba Hutani Mas (PT RHM) di Provinsi Jambi. Penelitian ini bertujuan untuk mengetahui dinamika struktur dan komposisi vegetasi antara pengukuran tahun 2018 dan 2020, khususnya pada areal dengan tutupan Belukar Tua (BT). Diameter semua pohon yang telah diberi tanda nomor pada tahun 2018 diukur kembali. Pohon yang belum diberi tanda sebelumnya tetapi diameternya $\geq 10 \mathrm{~cm}$ setinggi dada $(\mathrm{DBH})$ ditetapkan sebagai rekrutmen baru dan diberi tanda dengan nomor baru. Pengamatan dan analisis data dilakukan terhadap tiga tahap tahap pertumbuhan, yaitu tingkat pohon $(\geq 10 \mathrm{~cm}$ $\mathrm{DBH})$, tingkat pancang $(<10 \mathrm{~cm} \mathrm{DBH})$, dan tingkat semai (tinggi $<1,5 \mathrm{~m})$. Hasil penelitian menunjukkan bahwa jumlah spesies, jumlah marga, dan jumlah famili pada tingkat pohon dan pancang tinggi, sedangkan pada tingkat semai rendah. Jenis dominan pada tingkat pohon pada tahun 2018 adalah Alseodaphne bancana telah digantikan oleh Archidendron bubalinum pada tahun 2020, sedangkan pada tingkat pancang (Rothmania sp) dan tingkat semai (Aporusa microsphaera) merupakan jenis yang dominan baik pada tahun 2018 maupun pada tahun 2020. Angka kematian pada semua tahapan pertumbuhan bervariasi dengan rata-rata 4,67\%. Rekrutmen di tingkat pohon 2,67\% yang terdiri dari 8 spesies, 8 marga, dan 7 famili. Secara keseluruhan, semua spesies tersebar secara acak. Tinggi tajuk pohon didominasi oleh stratum C (tinggi 4 m - 20 m). Hasil pengujian hipotesis pada setiap tingkatan (pohon, pancang, semai) berbeda, namun hasil penggabungan semua data menunjukkan bahwa telah terjadi dinamika.
\end{abstract}

Keywords: Forest dynamics, early regeneration forest, structure and composition, Danau Bangko, Batanghari, Jambi, Indonesia

\section{INTRODUGTION}

Forests consist of biotic (like trees, animals, plants, and other living things) and abiotic (such as soil, water, air, and landforms) components. All of these components together make up a forest ecosystem.

Submitted 14 January 2021; Accepted 23 March 2021
Management designed to produce rational and optimal use of forest resources is based on long-term sustainability, not oriented towards or influenced by current short-term use. Sustainable forest management depends on a variety of data and information on the condition of the vegetation, including data on the dynamics of the stands from each 
period. Absolute data and information must be available as the basis for determining long-term management policy strategies, so as to maximize the benefits obtained based on the principle of sustainability.

Continuous deforestation has wide-ranging impacts, especially by reducing biodiversity, thereby weakening or removing links in the food chain in forest areas, and ultimately weakening the entire forest ecosystem. In 2004, when the company granted a permit to manage a production forest for industrial plantation forest, some blocks of remaining natural forest were set aside as protected areas within the industrial plantation forest (HTI) of PT. Rimba Hutani Mas (PT. RHM), Batanghari District, Jambi Province, which is one of them called as DBPA that aiming to preserve the complete range of forest habitats within the locality.

Based on the report of Samsoedin et al. (2018), the DBPA is divided into three land cover types, namely Early Regeneration Forest or Young Regeneration forest (YRF), Scrub (S), and Open Land (OL), as are used in the classification of the High Carbon Stock (HCS) area (Adriani et al., 2017).

The DBPA is a relatively intact forest area located within the plantation forest concession of PT. RHM, the latter dominated by eucalyptus (Eucalyptus pellita) and acacia (Acacia mangium). In addition to protecting an intact forest are, the DBPA provides and enhances a range of ecosystem services affecting the surrounding areas, particularly as a source of germplasm for several climax forest tree species that are still found in the DBPA (Samsoedin et al., 2018).

Monitoring forest areas continuously (time series) is a tool that can answer many hypotheses when studying forest growth dynamics. The permanent plot in the DBPA, which was established in 2018, is a natural laboratory for studying the dynamics of vegetation (succession), including stem diameter growth rates, mortality, natality, population growth, dominance, and recruitment. (Kusumo et al., 2016).

Vegetation studies using permanent plots in forest areas are still relatively rare, so relevant information is still limited, and little is known about the DBPA itself (Samsoedin, 2009). The challenge for this research was that there was no existing comprehensive information on the dynamics of the specific forest locality. The objective of the study was therefore to understand the dynamics of the vegetation structure and composition in the DBPA that occurred in the short term, over the two years following the setting up of the permanent plot.

forest concession of PT Rimba Hutani Mas (PT. RHM), which has set aside DBPA as the required protected area. Administratively, it is located in Lubuk Ruso Village, Subdistrict Pemayungan, Batanghari District, Jambi Province (Figure 1).

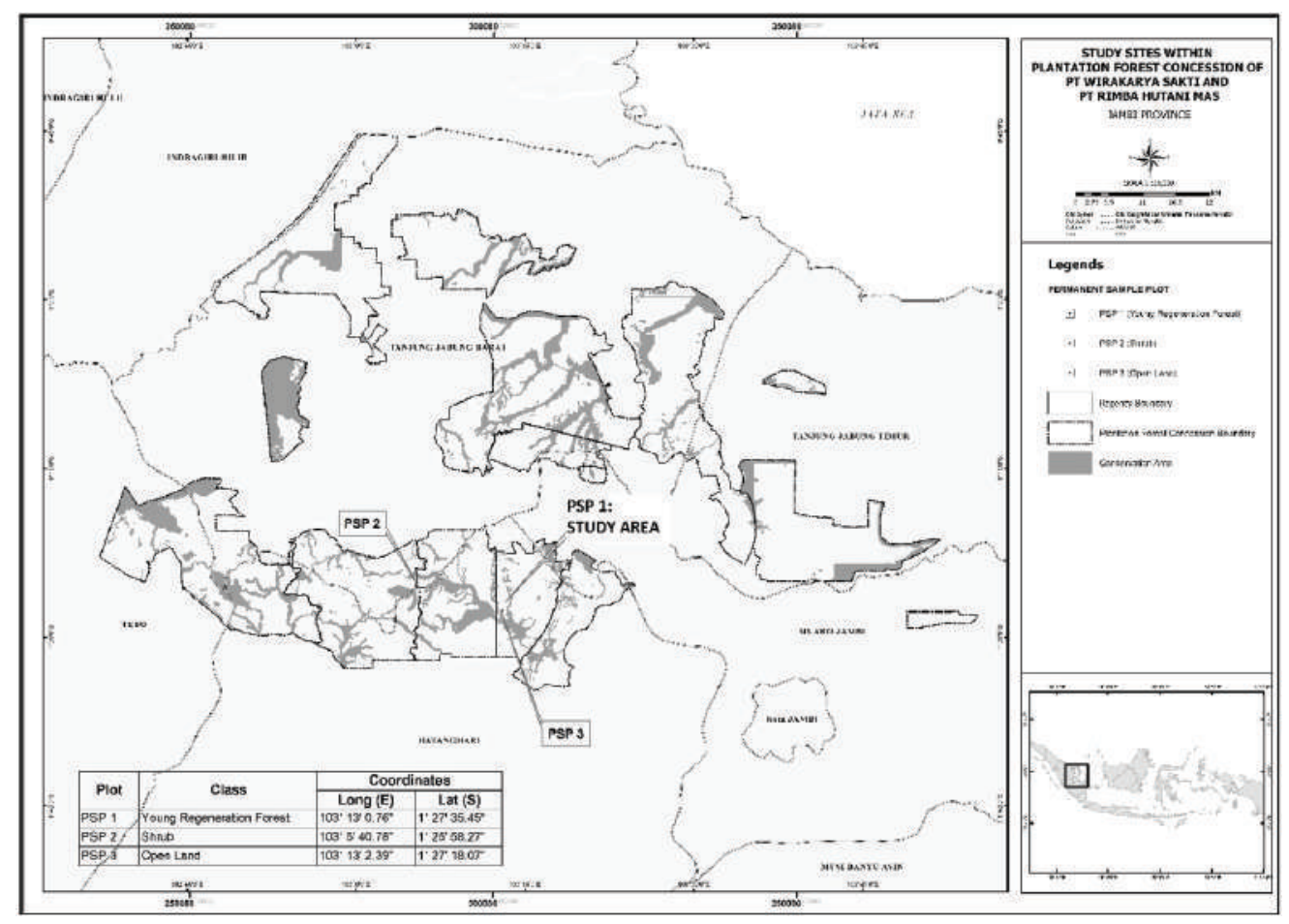

Figure 1. Location of the study area in the DBPA within PT. RHM concession, Jambi. 
Three phases of research activities were undertaken. Pre-field studies included preparation of tools and materials. The field research included re-measuring all trees that were tagged in 2018 as well as identifying newly recruited trees, and preparing herbarium samples. Post-field studies included data input and analysis, drying of herbarium samples, and taxonomic identification of the samples which carried out at the Botany Laboratory, Herbarium Bogoriense, Indonesian Institute of Sciences (LIPI), Cibinong, Bogor.

\section{General conditions of the study site}

The permanent plot is located within a lowland wet tropical forest area of the DBPA. It is geographically located at $1^{\circ} 27^{\prime} 33.5^{\prime \prime}$ South and $103^{\circ} 13^{\prime} 00.2^{\prime \prime}$ East with an elevation of $\pm 40 \mathrm{~m}$ above sea level (asl). Topographically, the area is a mix of flat and hilly areas with slopes ranging from $8 \%$ to $15 \%$. Soil types include alluvial associations consisting of acid tuff, sandstone, and sand deposits. There is a thick layer of red to yellow solum, with low nutrient content, which is easily eroded (Samsoedin et al., 2018). The microclimate within study area is considered to be type " $\mathrm{A}$ " based on Schmidt and Ferguson's climate classification (Schmidt \& Ferguson, 1951). Rainfall total was 958.7-1,613.5 $\mathrm{mm}$ over 57-73 days, the wet season being from February to June. Above ground biomass content varied between 167.6 tonnes/ha and 307.6 tonnes/ha (Samsoedin et al., 2018). Average air temperature was $28.78{ }^{\circ} \mathrm{C}\left(27.2-30.4{ }^{\circ} \mathrm{C}\right)$, soil temperature $28.50{ }^{\circ} \mathrm{C}$ $\left(27-30.2{ }^{\circ} \mathrm{C}\right)$, humidity level $82.40 \%(66 \%-89 \%)$, soil moisture $83.64 \%(69 \%-90 \%)$, and average soil $\mathrm{pH}$ $5.35(4-6)$.

\section{Data analysis}

All field data collected in 2020 from the permanent plot were processed and analysed following Mueller-Dombois \& Ellenberg (1974) as well as Soerianegara \& Indrawan (2014), using Excel software.

\section{RESULTS}

The analysis used data collected from the permanent plot collected in 2018 when the plot was first established and data from 2020. The data were categorized according to three growth phases, namely the tree, sapling and seedling phases, and in 2020 comprised a total of 101 species, 77 genera, and 38 families. The families represented by five or more species were Euphorbiaceae (11 species), Rubiaceae (eight species), Lauraceae (six species), Annonaceae (six species), Dipterocarpaceae (five species), and Myristicaceae (five species) (Heriyanto et al., 2020; Kartawinata et al., 2004; Samsoedin et al., 2018; Wardani \& Heriyanto, 2015).

\section{Composition and structure in the tree phase $(\geq 10 \mathrm{~cm} \mathrm{DBH})$}

This phase contained 83 species, 65 genera and 35 families, at a density of 485 trees/ha. The change in numbers from 2018 to 2020 was not statistically significant. The diversity index $\left(\mathrm{H}^{\prime}\right)$, number of species, number of genera, number of family, and basal area all increased from 2018 to 2020, but tree density decreased (Table 1). Thirteen tree species had been recruited $(2.67 \%)$ in the permanent plot between 2018 and 2020 (Table 2). These comprised eight species, eight genera, and seven families.

Sixteen trees died between 2018 and 2020 (mortality rate $2.88 \%$ ), consisting of 14 species, 13 genera, and 12 families (Table 3). Seven dominant species had an Important Value Index (IVI) >10\% (Table 4). The most dominant species is Archidendron bubalinum (IVI= $24.92 \%)$, with Alseodaphne bancana $(\mathrm{INP}=19.52 \%)$ as a subdominant. The distribution pattern of all species is random. The value of hypothesis test result is -1.28 which means that there has been dynamic within two years period (between the period of 2018 and 2020). The result of the analyses with Graphic of Trend (GT) also shows that there has been significantly dynamics, and it is predicted that there will continue to be development or dynamics.

Table 1. Characteristics of the tree phase in the 1-ha permanent plot.

\begin{tabular}{|l|c|c|}
\hline Parameter & $\mathbf{2 0 1 8}$ * & $\mathbf{2 0 2 0}$ \\
\hline Species diversity index $\left(\mathrm{H}^{\prime}\right)$ & 3.64 & 3.80 \\
\hline Richness index $(\mathbf{C})$ & 0.05 & 0.05 \\
\hline Similarity index $(\mathrm{E})$ & 0.05 & 0.32 \\
\hline Mortality (\%) & 0 & 2.88 \\
\hline Number of species & 75 & 83 \\
\hline Number of genera & 64 & 65 \\
\hline Number of families & 34 & 35 \\
\hline Density (trees/ha?) & 486 & 485 \\
\hline Basal area Units? & 19.74 & 20.09 \\
\hline $\begin{array}{l}\text { Frequency/distribution (Number of } \\
\text { individual trees?) }\end{array}$ & 344 & 335 \\
\hline
\end{tabular}

Note: *Samsoedin et al. (2018) 
Table 2. Species recruitment in the tree phase in 1-ha permanent plot.

\begin{tabular}{|c|c|c|c|c|c|}
\hline No. & Species & $\begin{array}{l}\text { DBH } \\
(\mathbf{c m})\end{array}$ & $\begin{array}{c}\text { Height } \\
\text { (m) }\end{array}$ & $\begin{array}{c}\text { Tagging } \\
\text { No. }\end{array}$ & $\begin{array}{l}\text { Subplot } \\
\text { location }\end{array}$ \\
\hline 1 & Ixora javanica* & 10.83 & 9.4 & 487 & A \\
\hline 2 & Endiandra rubescens* & 10.83 & 9.3 & 488 & A \\
\hline 3 & Sandoricum koetjape & 11.94 & 12.6 & 489 & $\mathrm{C}$ \\
\hline 4 & Neouvaria acuminatissima* & 10.51 & 12.2 & 490 & $\mathrm{G}$ \\
\hline 5 & Aglaia sp.* & 10.51 & 14.4 & 491 & $\mathrm{~L}$ \\
\hline 6 & Dyera costulata & 16.82 & 10.5 & 492 & $\mathrm{~T}$ \\
\hline 7 & Knema sp.* & 11.46 & 15.3 & 493 & $\mathrm{R}$ \\
\hline 8 & Alseodaphne bancana & 10.51 & 7.8 & 494 & $\mathrm{R}$ \\
\hline 9 & Diospyros frutescens* & 10.73 & 16.4 & 495 & $\mathrm{P}$ \\
\hline 10 & Baccaurea sp. $^{*}$ & 10.83 & 11.2 & 496 & $\mathrm{O}$ \\
\hline 11 & Canarium sp. & 10.38 & 15.4 & 497 & $\mathrm{Y}$ \\
\hline 12 & Antidesma cuspidatum * & 10.70 & 13.7 & 498 & $\mathrm{Y}$ \\
\hline 13 & Dacryodes rostrate & 11.11 & 16.3 & 499 & $\mathrm{~V}$ \\
\hline
\end{tabular}

Note: *New record in the plot

Table 3. Individual trees in 1-ha permanent plot found dead in 2020.

\begin{tabular}{|c|l|c|c|c|}
\hline No. & \multicolumn{1}{|c|}{ Species } & DBH (cm) & Height (m) & $\begin{array}{c}\text { Tagging } \\
\text { No. }\end{array}$ \\
\hline 1 & Agelaea trinervis & 17.70 & $1 ., 8$ & 248 \\
\hline 2 & Alseodphane bancana & 24.00 & 18.3 & 353 \\
\hline 3 & Alseodphane bancana & 11.20 & 89 & 209 \\
\hline 4 & Antidesma tomentosa & 11.10 & 13.0 & 115 \\
\hline 5 & Archidendron bubalinum & 13.50 & 9.2 & 352 \\
\hline 6 & Archidendron bubalinum & 13.50 & 22.4 & 60 \\
\hline 7 & Baccaurea motleyana & 12.00 & 8.8 & 157 \\
\hline 8 & Gaertnera sp. & 19.00 & 17.1 & 350 \\
\hline 9 & Kokoona reflexa & 25.00 & 20.9 & 198 \\
\hline 10 & Monocarpia sp. & 21.90 & 21.1 & 411 \\
\hline 11 & Palaquium ridleyi & 41.60 & 21.3 & 370 \\
\hline 12 & Rothmania sp. & 20.00 & 13.2 & 147 \\
\hline 13 & Sandoricum koetjape & 30.00 & 19.9 & 246 \\
\hline 14 & Santiria laevigata & 10.00 & 8.2 & 227 \\
\hline 15 & Shorea acuminate & 17.00 & 18.1 & 412 \\
\hline 16 & Syzygium sp. & 17.30 & 16.8 & 300 \\
\hline
\end{tabular}

Table 4. Species in tree phase with Important Value Index $(\mathrm{IVI})=>10 \%$ in 1 -ha permanent plot $(\mathrm{DR}=$ Relative Dominance; $\mathrm{KR}=$ Relative Density; $\mathrm{FR}=$ Relative Frequency).

\begin{tabular}{|l|c|c|c|c|}
\hline \multicolumn{1}{|c|}{ Species } & DR (\%) & KR (\%) & $\begin{array}{c}\text { FR } \\
(\%)\end{array}$ & $\begin{array}{c}\text { IVI } \\
(\%)\end{array}$ \\
\hline Archidendron bubalinum & 7.23 & 11.42 & 6.27 & 24.92 \\
\hline Alseodphane bancana & 7.83 & 6.61 & 5.07 & 19.52 \\
\hline Agelaea trinervis & 6.94 & 7.21 & 4.18 & 18.33 \\
\hline Ochanostachys amentacea & 6.66 & 5.81 & 4.18 & 16.65 \\
\hline Strombosia ceylanica & 7.27 & 2.81 & 2.39 & 12.47 \\
\hline Monocarpia sp. & 5.50 & 3.21 & 2.69 & 11.39 \\
\hline Sandoricum koetjape & 4.95 & 2.81 & 2.99 & 10.74 \\
\hline
\end{tabular}




\section{Growth in the sapling phase $(<10 \mathrm{~cm}$ DBH $)$}

The sapling level in 2020 consisted of 47 species, 43 genera, and 27 families with a sapling density of 218 trees/ $625 \mathrm{~m}^{2}$ (or 3,488 trees/ha). The results from 2018 and 2020 do not vary significantly. The 2020 Shannon Wiener $\left(\mathrm{H}^{\prime}\right)$ Index, density and basal area were higher than in 2018, but other parameters remain the same (Table 5).

Table 5. Characteristics of the sapling phase at the 1-ha permanent plot.

\begin{tabular}{|l|c|c|}
\hline \multicolumn{1}{|c|}{ Parameter } & $\mathbf{2 0 1 8} *$ & $\mathbf{2 0 2 0}$ \\
\hline Species diversity index $\left(\mathrm{H}^{\prime}\right)$ & 3.40 & 3.42 \\
\hline Richness index $€$ & 0.35 & 0.35 \\
\hline Similarity index $€$ & 0.88 & 0.88 \\
\hline Mortality $(\%)$ & 0 & 3.54 \\
\hline Number of species & 47 & 47 \\
\hline Number of genera & 43 & 43 \\
\hline Number of family & 27 & 27 \\
\hline Density & $226(3,616 / \mathrm{ha})$ & $218(3,488 / \mathrm{ha})$ \\
\hline Basal area & 0.18 & 0.21 \\
& $\left(2.88 \mathrm{~m}^{2} / \mathrm{ha}\right)$ & $\left(3.36 \mathrm{~m}^{2} / \mathrm{ha}\right)$ \\
\hline
\end{tabular}

The mortality rate of saplings over the two years was $3.54 \%$ (eight saplings) (Table 6). There are ten dominant species in 2020 with IVI $>10 \%$ (Table 7), the most dominant being Rothmania sp. (IVI= $23.17 \%$ ), followed by Aporusa microsphaera (IVI= 19.68\%). The most dominant species at sapling phase in 2018 was also Rothmania sp. (IVI= 28.45\%), , (with an increased IVI The dominance and IVI of other species had shifted from 2018 to 2020, with some species' IVI increasing to $>10$ in 2020, e.g., Gonocaryum littorale (IVI= $12.94 \%$ ) and Ixora siamensis (IVI= 10,67\%).

The distribution pattern of species within this phase is also random. The hypothesis test results is -1.03 indicating significant change in the plot structure within this phase. The analyses of GT shows that there

Table 6. Individual saplings in 1-ha permanent plot found dead in 2020

\begin{tabular}{|l|c|c|}
\hline \multicolumn{1}{|c|}{ Species } & $\begin{array}{c}\text { DBH } \\
(\mathbf{c m})\end{array}$ & $\begin{array}{c}\text { Height } \\
(\mathbf{m})\end{array}$ \\
\hline Alseodphane bancana & 6.0 & 11.4 \\
\hline Archidendron bubalinum & 3.0 & 4.8 \\
\hline Diospyros bantamensis & 1.0 & 3.1 \\
\hline Diospyros bantamensis & 1.0 & 2.6 \\
\hline Paraserianthes falcataria & 7.5 & 6.8 \\
\hline Pimelodendron griffithïamum & 7.6 & 5.2 \\
\hline Prunus arborea & 2.5 & 5.8 \\
\hline Syzygium clavimyrtus & 0.5 & 2.1 \\
\hline
\end{tabular}

is a change but that is not as significant as in the tree phase $\left(\mathbf{R}^{2}=0.81\right)$.

Table 7. Species in the sapling phase with Important Value Index $(\mathrm{IVI})=>10 \%$ in 1-ha permanent plot $(\mathrm{DR}=$ Relative Dominance; $\mathrm{KR}=$ Relative Density; $\mathrm{FR}=$ Relative Frequency).

\begin{tabular}{|l|c|c|c|c|}
\hline \multicolumn{1}{|c|}{ Species } & $\begin{array}{c}\text { KR } \\
(\mathbf{\%})\end{array}$ & $\begin{array}{c}\text { FR } \\
(\mathbf{\%})\end{array}$ & $\begin{array}{c}\text { DR } \\
(\mathbf{\%})\end{array}$ & $\begin{array}{c}\text { IVI } \\
(\mathbf{\%})\end{array}$ \\
\hline Rothmania sp. & 7.60 & 8.26 & 7.32 & 23.17 \\
\hline Aporusa micosphaera & 7.77 & 6.42 & 5.49 & 19.68 \\
\hline Archidendron bubalinum & 7.82 & 5.50 & 4.88 & 18.20 \\
\hline Monocarpia sp. & 5.47 & 5.96 & 5.49 & 16.92 \\
\hline Hydnocarpus woodii & 4.58 & 5.96 & 5.49 & 16.03 \\
\hline Dacryodes rostrata & 4.92 & 5.50 & 5.49 & 15.91 \\
\hline Sterculia oblongata & 4.10 & 6.42 & 4.88 & 15.40 \\
\hline Ochanostachys amentacea & 4.28 & 5.96 & 4.88 & 15.12 \\
\hline Gonocaryum litorale & 3.01 & 5.05 & 4.88 & 12.94 \\
\hline Ixora simalurensis & 3.34 & 3.67 & 3.66 & 10.67 \\
\hline
\end{tabular}

\section{Growth in the seedling phase (height $<1.5 \mathrm{~m}$ )}

Within the seedling phase, most of the parameters (diversity, richness and similarity indexes, and number of species and family) decreased from 2018 to 2020. In 2020, there were 28 species, 27 genera, and 21 families (Table 8). The mortality rate was $8.44 \%$, with the loss of 12 trees and saplings species. There are six dominant species (five families) within the sapling phase with an IVI $=>10 \%$ (Table 9$)$.

Aporosa micosphaera $(\mathrm{IVI}=30.32 \%$ ) was the most dominant species in 2018 and in 2020, although there was a change in the IVI values for other species, including Monocarpia sp. which was replaced in 2020 by Archidendron bubalinum.

Table 8. Characteristics of the seedling phase at 1-ha permanent plot.

\begin{tabular}{|l|c|c|}
\hline \multicolumn{1}{|c|}{ Parameter } & 2018* & 2020 \\
\hline Species diversity index $\left(\mathrm{H}^{\prime}\right)$ & 2.78 & 2.70 \\
\hline Richness index $(\mathrm{C})$ & 0.54 & 0.42 \\
\hline Similarity index $(\mathrm{E})$ & 0.82 & 0.81 \\
\hline Mortality $\%$ \%) & 0 & 8.44 \\
\hline Number of species & 30 & 28 \\
\hline Number of genera & 29 & 27 \\
\hline Number of family & 22 & 21 \\
\hline & 154 & 142 \\
Density & $(15,400 / \mathrm{ha})$ & $(14,200 / \mathrm{ha})$ \\
\hline
\end{tabular}

Note: *Samsoedin et al. (2018) 
There was no additional species recruitment into the seedling phase by 2020, but two species decreased, namely Gluta velutina and Hydnocarpus woodii. Thirteen seedlings (from seven species and five families) died (mortality rate $8.44 \%$ ) (Table 10). The species distribution pattern at this phase was again random, and the hypothesis test shows that low levels of dynamics.

\begin{tabular}{|l|c|c|c|}
\hline \multicolumn{1}{|c|}{ Species } & KR (\%) & FR (\%) & $\begin{array}{c}\text { IVI } \\
\mathbf{( \% )}\end{array}$ \\
\hline Aporusa micosphaera & 16.90 & 13.41 & 30.32 \\
\hline Archidendron bubalinum & 14.08 & 976 & 23.84 \\
\hline Monocarpia sp. & 14.08 & 8.54 & 22.62 \\
\hline Rothmania sp. & 13.38 & 6.10 & 19.48 \\
\hline Strombosia ceylanica & 4.93 & 8.54 & 13.47 \\
\hline Ixora simalurensis & 4.93 & 6.10 & 11.03 \\
\hline
\end{tabular}

Table 10. Species in seedling phase in 1-ha permanent plot found dead in 2020

\begin{tabular}{|c|l|c|c|}
\hline No. & \multicolumn{1}{|c|}{ Species } & Family & N \\
\hline 1 & Rothmania sp. & Rubiaceae & 4 \\
\hline 2 & Ixora simalurensis & Rubiaceae & 2 \\
\hline 3 & Ixora sp. & Rubiaceae & 1 \\
\hline 4 & Strombosia ceylanica & Olacaceae & 1 \\
\hline 5 & Gluta velutina & Guttiferae & 1 \\
\hline 6 & Hydnocarpus woodii & Flacourtiaceae & 1 \\
\hline 7 & Monocarpia sp. & Annonaceae & 3 \\
\hline \multicolumn{3}{|c|}{ Total } & 13 \\
\hline
\end{tabular}

\section{Forest regeneration}

Regeneration in the tree phase is relatively good (Figure 2). The area is dominated by trees with a DBH of $10-19.9 \mathrm{~cm}$ (299 trees / 61.65\%). Trees with a DBH of $>50 \mathrm{~cm}$ are least frequent ( 6 trees $/ 1.24 \%$ ). The sapling phase is dominated by those with a DBH of $1-2.9 \mathrm{~cm}$ (116 trees / 53.21\%), and the least common are those with a DBH of $6-9.9 \mathrm{~cm}$ (24 trees / 11.01\%). The 2020 survey showed that 15 species (11 families) have been recruited across all growth phases (tree, sapling, seedling) since 2018 (Table 11).

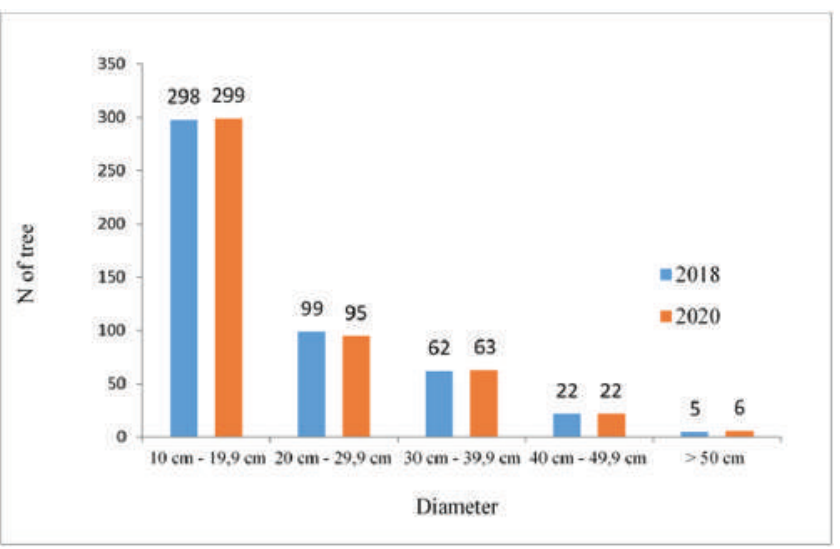

Figure 2. Distribution of all tree diameter classes $(>10 \mathrm{~cm}$ DBH) within a 1-ha permanent plot in 2018-2020.
In the tree and sapling phases, six species showed a DBH increase $>0.1 \mathrm{~cm}$, the highest growth occurring in Archidendron bubalinum (average $1.04 \mathrm{~cm}$ ) and the lowest in Strombosia ceylanica (average $=0.23 \mathrm{~cm}$ ). The average growth of all other species is $<0.1 \mathrm{~cm}$ (Table 12).

Table 11. Species occurring in all growth phases in 1-ha permanent plot.

\begin{tabular}{|l|c|c|c|}
\hline \multirow{2}{*}{ Species } & \multicolumn{3}{|c|}{ IVI (\%) } \\
\cline { 2 - 4 } & Tree & Sapling & Seedling \\
\hline Agelaea trinervis & $18.33(3)^{*}$ & 2.43 & 1.92 \\
\hline Alseodphane bancana & $19.52(2)^{*}$ & 9.74 & 1.92 \\
\hline Aporusa micosphaera & 0.56 & $19.68(2)^{*}$ & $30.32(1)^{*}$ \\
\hline Aporusa sphaeridophora & 0.61 & 5.93 & 3.85 \\
\hline Archidendron bubalinum & $24.92(1)^{*}$ & $18.20(3)^{*}$ & $23.84(2)^{*}$ \\
\hline Baccaurea motleyana & 4.14 & 5.98 & 9.62 \\
\hline Dacryodes rostrata & 4.76 & $15.91(6)^{*}$ & 1.92 \\
\hline Diospyros bantamensis & 4.49 & 5.04 & 4.55 \\
\hline Gompia serrata & 1.16 & 1,22 & 7.69 \\
\hline Ixora simalurensis & 3.22 & $10.67(10)^{*}$ & $11.03(6)^{*}$ \\
\hline Litsea tomentosa & 4.98 & 1.14 & 1.92 \\
\hline Monocarpia sp. & $11.80(6)^{*}$ & $16.92(4)^{*}$ & $22.62(3)^{*}$ \\
\hline Ochanostachys amentacea & 19.86 & $15.12(8)^{*}$ & 6.48 \\
\hline Rothmania sp. & 9.34 & $23.17(1)^{*}$ & $19.48(4)^{*}$ \\
\hline Xanthophyllum excelsum & 2.24 & 5.93 & 1.92 \\
\hline
\end{tabular}

Note: $*$ IVI $=>10 \%$

Table 12. Species with highest increase in DBH during the period 2018-2020 in 1-ha permanent plot.

\begin{tabular}{|l|l|c|}
\hline Species & Family & $\begin{array}{c}\text { Mean DBH } \\
\text { growth } \mathbf{( \text { cm) }}\end{array}$ \\
\hline Archidendron bubalinum & Leguminosae & 1.04 \\
\hline Bouea oppositifolia & Anacardiaceae & 0.49 \\
\hline Koompassia malaccensis & Caesalpinaceae & 0.72 \\
\hline Nephelium mutabile & Sapindaceae & 0.13 \\
\hline Sandoricum koetjape & Meliaceae & 0.17 \\
\hline Strombosia ceylanica & Olacaceae & 0.23 \\
\hline
\end{tabular}

\section{Forest stratification}

Tree stand structures in various diameter classes are horizontally spread across subplots A-Y within the 1 haa permanent plot (Figure 3). The tallest tree is $32 \mathrm{~m}$ in height and the smallest is $7 \mathrm{~m}$, with an average of $15.17 \mathrm{~m}$. The tallest in the sapling phase is $11.4 \mathrm{~m}$ and the smallest $1.2 \mathrm{~m}$, with an average of $3.77 \mathrm{~m}$. Overall, canopy cover averages $40 \%$, or classified as medium category according to Indriyanto ( 2008).

The tree canopy within study area is divided into three strata. Trees in stratum C (4-20 m height) are most dominant, followed by those in stratum B (20-30 $\mathrm{m}$ height), and stratum A with trees $>30 \mathrm{~m}$. The highest percentage of species at stratum $\mathrm{C}$ (which greater than $5 \%$ are Alseodphane bancana (75 trees / 18.75\%), Ochanostachys amentacea (32 trees / 8.00\%), and Agelaea trinervis (25 trees / 6.25\%). While the family in stratum C which greater than $10 \%$ are Leguminosae (47 trees / $11.75 \%$ ). The highest percentage of species at stratum 
B (which greater than 5\%) are including Diospyros bantamensis (7 trees / 8.33\%), Bouea oppositifolia (6 trees / 7.14\%), Dehaasia sp. (6 trees / 7.14\%), Barringtonia racemosa (5 trees / 5.95\%), and Baccaurea motleyana (5 trees / 5.95\%). Stratum A only contains one species $(0.21 \%)$, namely Horsfieldia glabra.

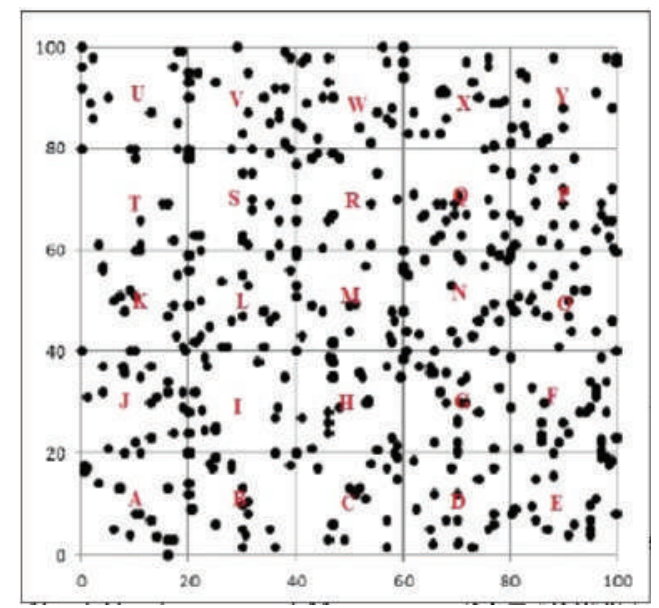

Figure 3. Distribution of trees $(\geq 10 \mathrm{~cm} \mathrm{DBH})$ in subplots within the permanent plot in 2020 .

\section{Similarity index}

The Similarity index (SI) is used to determine the similarity of a species which has IVI $=>10 \%$ within 25 subplots. The results of the analyses showed that most of species are different, and only three species have a SI index $>50 \%$. The highest correlation occurs between Alseodaphne bancana and Mococaria sp. (SI = $52.25 \%$ ) with Ochanostachys amentacea (SI = $50.03 \%$ ). The correlation among other species is $<50 \%$, some even tends to uncorrelated such as Strombosia ceylanica $(\mathrm{SI}=31.44 \%)$. The occurrence of different correlation between these species means that the symbiosis between species is considered as low mutualism (Figure 4). There are eight subplots that have SI > 50\% while another 17 subplots have SI < $50 \%$, this means that each subplot has a relatively different condition.

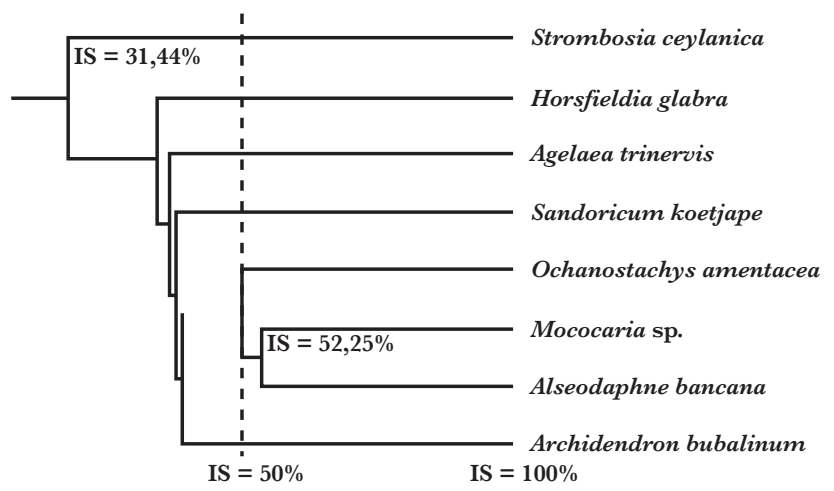

Figure 4. Percentage of tree species correlation IVI $=>10 \%$ within one hectare permanent plot.

\section{DISGUSSION}

Indonesia's forests are among the most diverse and the most threatened in the world, especially lowland rainforest (occurring below 500 metres asl). The country's largest remaining tract of lowland rainforest is located on Sumatra, and this includedthe forest area within DBPA (Suwardi et al., 2013 in Sadili et al., 2019).

Permanent plots can contribute significantly to our understanding of the dynamics of lowland rainforest and its resilience in the face of different disturbances, but few such plots exist in Indonesia. The 1-ha plot examined here was only set up two years ago and the various analyses presented here indicate change but nothing statistically significant(Table 1, 5, 8). According to Kuswandi (2017), a 1-ha permanent plot that is observed periodically for more than fiveyears is sufficiently representative of the area to illustrate the dynamics of growth. The permanent plot within DBPA is therefore still included in the category of YRF, with DBH measurements being predominantly relatively small (Figure 2).

Altitude affects the diversity of natural forest in one hectare of lowland forest there are usually more than 150 tree species (Whitmore, 1994). Mansur et al. (2010) found 123 and 126 tree species/ha in two plots in a lowland area of Harapan Rainforest, Jambi, Central Sumatra. . The tree species diversity in DBPA is lower than in Harapan. This is because the vegetation conditions in the two forest areas are different, where the vegetation conditions in Harapan Rainforest is better, while in DBPA used to be heavily logged before 2004. Tree species richness in DBPA is also lower than the eastern core zone of Bukit Duabelas National Park, Jambi, which is consisting of 113 species and 38 families (Rahmah et al., 2016). Moreover, the tree species diversity in both areas is lower than in the lowland rainforest of Sekundur, Gunung Leuser National Park in Northern Sumatra, which has 133 species (39 families) (Priatna et al., 2006). The tree species richness and tree density in DBPA is also lower than in a permanent plot located ini Bodogol, Gunung Gede Pangrango National Park, West Java, which has 119 species (44 families) (Sadili, 2014; 2018).

The mean mortality rate of species measured in DBPA over the two years was $4.67 \%$ (trees, saplings, seedlings). This mortality rate indicates that the successional process is still a long way from reaching a climax forest, because the natural climax tropical forests usually have a mortality rate of $1 \%-2 \%$ /year. In addition, the DBPA permanent plot is characterized by many species of shrubs and pioneer trees (fast growing species), but already some slow-growing families are also present, such as Lauraceae, Annonaceae, Dipterocarpaceae, Myristicaceae, Fagaceae, and Burseraceae. 
Euphorbiaceae (11 species) and Rubiaceae (eight species) are two of the largest families in Malaysiana flora, but they usually occupy the lower or middle forest strata. Euphorbiaceae's success in dominating many forest types is evidence that this family is highly adaptableto environmental conditions and opportunistic (Proctor at al, 1983; Priatna et al., 2006; Sadili, 2014).

Occurrence of gaps in the forest canopy can stimulate dormant seeds of pioneer tree species are growing up, and provide opportunities for of several species of shrubs to develop, so that plant species show a mixture of pioneer trees and shrub species. Based on visual observation, several small gaps also formed both in and around the permanent plot due to naturally broken tree branches. Indriyanto (2008) classify forest canopy covers into three different phases namely high $(>70 \%)$, moderate $(40-70 \%)$, and low $(<40 \%)$.

The similarity index (SI) determines the level of similarity or degree of grouping among several objects under the study using several variables (positive or negative collaboration). In this study we employed SI to measuring whether the composition of the plant community in each sub-plot is similar. According to Kramer \& Kozlowski (1979) in Pamoengkas \& Prayogi (2011), growth is the end result of the interaction of various physiological processes that are influenced by environmental conditions. The picture of the species correlation of IVI $>10 \%$ is mostly low ( $\mathrm{SI}=<50 \%$ ), which means that there is no high mutualism symbiosis. Then the results of the analysis for 25 different subplots (SI $=<50 \%$ ), shows that the research area within permanent plot is representative (heterogeneous subplots).

The distribution of all tree diameter classes $(\geq 10 \mathrm{~cm}$ DBH) within a 1-ha permanent plot in 2018-2020 can be seen in (Figure 2). This shows common condition of a natural tropical forests including in permanent plot, and is called the "inverted J" type. This pattern is a characteristic of dynamic natural forests (Proctor et al., 1983; Samsoedin \& Heriyanto, 2010).

Knowing the species distribution pattern is very important for basic forest management. Many factors influence these distribution patterns, particularly climatic conditions and nutrient availability (Sofiah et al., 2013). According to Wahyuni et al. (2017), random distribution patterns of plant species occur when the dispersal of their seeds is mostly by wind or animals, and when the species displays significant environmentally tolerance. This study shows that the overall distribution pattern of the tree species is random, which is indicating that they are mainly plant species that dispersed by wind or animals.

High IVI values such as Archidendron bubalinum (tree), Rotmania sp. (sapling), and Aporusa microsphaera (seedling) are species that have a big opportunity of maintaining their growth and sustainability because the dominant species is the species that can utilize the environment where they grow in more efficiently than other species in the same area. The results of this study indicate that those three species, Archidendron bubalinum, Rotmania sp., and Aporusa microsphaera, are the most dominant species in each growth phases (tree, sapling and seedling) in the plant communities within the DBPA forest.

The Dipterocarpaceae are one of the main constituent families of Indonesia's lowland forests, particularly in Sumatra (Purwaningsih, 2004) and five Dipterocarp species were recorded in the permanent plot area, namely Shorea acuminata, S. hemsleyana, S. leprosula, Dipterocarpus hasseltii, and Vatica rassak. Not all species were recorded in all growthphases. Shorea leprosula was only found in the seedling phase, while Shorea acuminata occurred in both seedling and sapling phases. Other species are only recorded in the tree phase, so at this point, Shorea acuminata is the most dominat of the Dipterocarp species.

The emergent layer was categorized as very poor because only one single species and single tree was recorded in that emergent layer ( $>30$ meters height). Natural, undisturbed forests of Sumatra and Kalimantan are usually dominated by members of Dipterocarpaceae, Burseraceae, and Leguminosae in the emergent layer. Again, this is an indication the permanent plot has had previously been disturbed and heavily logged, because based on its history, prior to 2004 this DBPA area was a logging concession area which was accompanied by illegal logging activities.

\section{GONGLUSION}

1. In a 1-ha permanent plot in Central Sumatra, we found a total of 101 species, 77 genera, and 38 families occurring in the tree, sapling, and seedling phases. All species are randomly dispersed.

2. Archidendron bubalinum, Rothmania sp., and Aporusa microsphaera are the most dominant species in the growth phases of tree, sapling and seedling, respectively.

3. Regeneration as manifested in the tree and sapling phases is quite good, but not in the seedling phase. Basal area, or stand density of trees and saplings, had increased over the two years by $3.64 \%$.

4. Eight species, eight genera, and seven families had been recruited into the permanent plot from 2018 to 2020.

5. Mortality rates in all growth phases (tree, sapling and seedling) is $4.67 \%$ across $2018-2020$, or $2.34 \%$ / year.

6. Tree densities are $485 /$ ha in the tree phase, 3,488 /ha in the sapling phase, and $14,200 /$ ha in the seedling phase. 
7. Overall, the analyses indicatethat permanent plot has experience some growth dynamics in tree and sapling phases but not in the seedling phase.

\section{ACKNOWLEDGMENTS}

The first author would like to thank the Head of the Botany Division and the Head of the Research Center for Biology-LIPI who granted research permission. Thank you also to Dr. Nurdin Sulistiyono (University of North Sumatra as Survey Team Leader), Rudi Halomoan Situmorang, Suranto Amelia, Vina Oktaviana, Arief Rahman Putra, and Rohman (PT. Rimba Hutani Mas, Jambi), as well as Andren Pradana, Ridho Anggara Kusuma, Eki Rahman, and Rio (PT. Wirakarya Sakti, Jambi). All authors would like to thank Prof. Kathryn A. Monk for providing critical input and proofreading on the manuscript. This study was supported by APP Sinar Mas as part of the research cooperation between APP Sinar Mas with Pusat Penelitian dan Pengembangan Hutan (P3H) and the Pusat Penelitian dan Pengembangan Sosial Ekonomi Kebijakan dan Perubahan Iklim (P3SEKPI).

\section{REFERENGES}

Adriani, Z. I, Anderson, P., Aritonang, S., Ballhorn, U., Barclay, B., Chao, S., Colchester, M., Crawshaw, J., Eickhoff, G., Ewers, R., Ghazoul, J., Hoyle, D., Kuru, G., Lemaistre, P., Lim, P. L., Lucey,J., Mc William, R., Navratil, P., Nejedlá,J., Ng, G., Olsson, A., Opal, G., Orth, M. P., Persch, S., Pescott, M., Proklamasi, S. A., Rafina, I., Rosoman, G., Senior, S., Struebig, M., Sugiyanto, T. A., Suhada, A. S., Thorp, T., Ende, S., Villalpando, P., \& Zrust, M. (2017). The HCS Approach Toolkit. Rosoman, G., Sheun, S.S., Opal, C., Anderson, P. \& Trapshah, R. (Eds.). HCS Approach Steering Group, Singapore.

Heriyanto, N.M. \& Garsetiasih, R. (2002). Studi status kelangkaan jenis pohon dari famili Dipterocarpaceae di hutan Lindung Sungai Wain, Kalimantan Timur. Bulletin Penelitian Hutan 631: 30-40.

Heriyanto, N. M., Priatna, D., \& Samsoedin, I. (2020). Struktur tegakan dan serapan karbon pada hutan sekunder kelompok hutan Muara Merang, Sumatera Selatan. Jurnal Sylva Lestari 8 (2): 230-240.

Indriyanto. (2008). Pengantar Budi Daya Hutan. Bumi Aksara, Jakarta.

Kartawinata, K., Samsoedin, I., Heriyanto, N.M., \& Afriastini, J.J. (2004). A tree species inventory in a one-hectare plot at the Batang Gadis National Park, North Sumatera, Indonesia. Reinwardtia 12 (2): 145-157.

Kusumo, A, Bambang, A.N., \& Izzati, M. (2016). Struktur vegetasi kawasan hutan alam dan hutan rerdegradasi di Taman Nasional Tesso Nilo. Jurnal Ilmu Lingkungan 14 (1): 19-26.
Kuswandi, R. (2017). Model pertumbuhan tegakan hutan alam bekas tebangan dengan sistem tebang pilih di Papua. Jurnal Pemuliaan Tanaman Hutan 11 (1): 45-55.

Mansur, M., Triono, T., Ismail., Adi, S W., Wahyu, E., \& Ismail, G. (2010). Analisis vegetasi pohon di hutan hujan tropik Harapan, Jambi. Berita Biologi 10 (2): 173-178.

Mueller-Dombois, D. \& Ellenberg, H. (1974). Aims and Methods of Vegetation Ecology. John Wiley and Sons, New York.

Pamoengkas, P., \& Prayogi, J. (2011). Pertumbuhan Meranti Merah (Shorea leprosula Miq.) dalam sistem silvikultur tebang pilih tanam jalur (Studi kasus di areal IUPHHK-HA PT. Sari Bumi Kusuma, Kalimantan Tengah. Jurnal Silvikultur Tropika 2 (1): 9-13.

Priatna, D., Kartawinata, K., \& Abdulhadi, R. (2006). Recovery of a lowland Dipterocarp forest twenty two years after selective logging at Sekundur, Gunung Leuser National Park, North Sumatra, Indonesia. Reinwardtia 12 (3): 237-255.

Proctor, J., Anderson, J.M., Fogden, S.C. \& Vallack, H.W. (1983). Ecological studies in four contrasting lowland rain forest in Gunung Mulu National Park. Sarawak. Jurnal Ecology 71: 261-283.

Purwaningsih. (2004). Sebaran ekologi jenis-jenis Dipterocarpaceae di Indonesia. Biodiversitas 5 (2): 89-95.

Rahmah, Kartawinata, K., Nisyawati, Ardhana W. \& Nurdin, E. (2016). Tree species diversity in the lowland forest of the core zone of The Bukit Duabelas National Park, Jambi, Indonesia. Reinwardtia 15 (1): 11-26.

Sadili, A. (2014). Dinamika vegetasi pada petak permanen rasamala (Altingia excelsa Noronha) di Bodogol, Taman Nasional Gunung Gede Pangrango, Jawa Barat. Furnal Biologi Indonesia 10 (1): 1-9.

Sadili, A., Kartawinata, K., Soedjito, H. \& Sambas, E.N. (2018). Tree species diversity in a pristine montane forest previously untouched by human activities in Foja Mountains, Papua, Indonesia. Reinwardtia 17 (2): 133-154.

Sadili, A., Royyani, M. F., Agusta, A., Afandi, I., Efendy, O., Ashari, H. \& Keim, A.P. (2019). Kajian pendahuluan floristik dan fitososiologi pohon di Pulau Simeuleu Provinsi Aceh. Jurnal Biologi Indonesia 15 (2): 187-197.

Samsoedin, I. (2009). Dinamika keanekaragaman jenis pohon pada hutan produksi bekas tebangan di Kalimantan Timur. Jurnal Penelitian Hutan Dan Konservasi Alam 6(1): 69-78

Samsoedin, I. \& Heriyanto, N.M. (2010). Struktur dan komposisi hutan pamah bekas tebangan ilegal di kelompok hutan Sei Lepan, Sei Serdang, Taman Nasional Gunung Leuser, Sumatera Utara. Furnal Penelitian Hutan dan Konservasi Alam 8 (3): 299-314. 
Samsoedin I., Heriyanto, N.M., Priatna, D., Supriatno, Wiharjo, U. \& Laksana, E. (2018). Struktur dan komposisi vegetasi serta kandungan karbon di kelompok hutan Danau Bangko PT. Rimba Hutani Mas dan Distrik III PT. Wirakarya Sakti, Kabupaten Batanghari, Propinsi Jambi. Laporan. Pusat Penelitian dan Pengembangan Hutan \& Pusat Penelitian dan Pengembangan Sosial Ekonomi Kebijakan dan Perubahan Iklim, Kementerian Lingkungan Hidup dan Kehutanan.

Schmidt, F.H. \& Ferguson, J.H.A. (1951). Rainfall Type Based on Wet and Dry Period Ratios for Indonesia with Western New Guinea. Verhandelingen Djawatan Meterologi de Geofisik, Jakarta.

Soerianegara, I. \& Indrawan, A. (2014). Ekologi Hutan Indonesia. Laboratorium Ekologi Hutan. Fakultas Kehutanan IPB, Bogor.
Sofiah S., Setiadi D. \& Widyatmoko, D. (2013). Pola penyebaran, kelimpahan dan asosiasi bambu pada komunitas tumbuhan di Taman Wisata Alam Gunung Baung Jawa Timur. Berita Biologi 12 (2): 239-247.

Wahyuni, A.S., Prasetyo, L.B. \& Zuhud, W.A.M. ( 2017). Populasi dan pola distribusi tumbuhan paliasa (Kleinhovia hospita L.) di Kecamatan Bontobahari. Media Konservasi 22 (1): 11-18.

Wardani, M. \& Heriyanto, N.M. (2015). Autoekologi damar asam [Shorea hopeifolia (F. Heim) Symington] di Taman Nasional Bukit Barisan Selatan, Lampung. Bulletin Plasma Nutfah 21 (2): 89-98.

Whitmore, T. C. (1994). Tropical Rain Forest of the Far East. Glarendon Press, Oxford. 